\title{
Telemedicine in Europe - Current Status and Future Perspectives
}

Ana-Maria $\mathrm{CIOTI}^{1}$, Ana Maria Alexandra STANESCU², Ioana Veronica GRAJDEANU ${ }^{1,2}$, Bogdan SERBAN², Elena POPESCU ${ }^{2,3}$, Ovidiu Gabriel BRATU2,4, Camelia Cristina DIACONU ${ }^{2,5}$

\begin{abstract}
Telemedicine ensures remote medical services through technologies that facilitate the interaction between a health professional and patients and offers the possibility of a interdiciplinary consultation between specialists, in order to obtain a diagnosis and treatment plan. It involves secure transmission of medical data and information, through text, sound, images or other forms needed for the prevention, diagnosis, treatment and follow-up of patients. With the help of telemedicine, people from rural areas, with dificult access to primary care, and those with reduced mobility can benefit from healthcare services. This paper is a review of the latest data available in the literature regarding telemedicine and the future prespectives in this field in Europe.
\end{abstract}

Keywords: telemedicine, telehealth, complementary medicine.

\section{Rezumat}

Telemedicina asigură furnizarea serviciilor medicale la distanță prin intermediul tehnologiei, facilitând interacțiunea dintre un profesionist din domeniul sănătății (medic, farmacist sau asistent medical) și pacienți, oferind posibilitatea consulturilor interdisciplinare între medicii specialiști, cu scopul obținerii unui diagnostic și a unui plan de tratament. Implică transmisia sigură de date și informații medicale, prin text, sunet, imagini sau alte forme necesare pentru prevenție, diagnosticul, tratamentul și urmărirea pacienților. Prin intermediul telemedicinei pot beneficia de îngrijiri medicale persoane din zonele rurale, cu acces dificil la sistemul de îngrijire primar sau de specialitate sau persoanele cu mobilitate redusă. Această lucrare este o trecere în revistă a informatiilor de actualitate disponibile în literatura de specialitate referitoare la telemedicină dar și a perspectivelor de viitor în acest domeniu în Europa.

Cuvinte cheie: telemedicină, telesănătate, medicină complementară.

\section{INTRODUCTION}

Telemedicine may be a solution for cases in which the geographical distance impaires access to specialized healthcare, such as rural areas or developing countries with poor health infrastructure ${ }^{1}$. Medical treatment in these conditions would require long distance travel, both energy and time-consuming - either for doctors or for the patients who may be in a poor health or financial state. Thus, most of the times, patients are often deprived of the adequate healthcare they need ${ }^{2,3}$.

In recent years, the technological development that allows rapid data analysis, artificial intelligence and Internet use in the health field have brought changes in traditional medicine, transforming the medical services. The increasing number of wearable and health-

\footnotetext{
'Private Medical Practice "Dr. Grajdeanu loana Veronica", Bucharest, Romania

2 "Carol Davila" University of Medicine and Pharmacy, Bucharest, Romania

${ }^{3}$ Ilfov County Clinical Emergency Hospital, Bucharest, Romania

${ }^{4}$ "Carol Davila" University Emergency Central Military Hospital,

Academy of Romanian Scientists, Bucharest, Romania

${ }^{5}$ Clinical Emergency Hospital of Bucharest, Bucharest, Romania
}

\section{Corresponding author.}

Ana Maria Alexandra STANESCU, „Carol Davila” University of

Medicine and Pharmacy, Bucharest, Romania.

E-mail: alexandrazotta@yahoo.com 
related devices helps implement large-scale telemedicine solutions ${ }^{3}$. In 2016, 79\% of EU residents aged 16 to 74 years have accessed the Internet using either their mobile phone or smartphone and the degree of digital literacy is on the rise ${ }^{4}$.

Telemedicine provides specific medical services, including teleconsultation, telemonitoring, teleeducation, telesurgery, teleconference, etc ${ }^{5}$. Telemedicine allows remote monitoring and reassessment, ensuring continuity of day to day care at significantly lower costs than hospitalization. Transmission of vital signs and other medical data, by devices that the patients use, to a remote control center helps create a broader information base for clinical decision making ${ }^{3}$. Telemonitoring has the potential to bring improvements to the management of patients suffering from chronic diseases. This ensures access to health care services for patients that are located far from hospitals or clinics, simplifying the process of prevention, patient management, monitoring and reassessment ${ }^{6}$. Furthermore, in addition to monitoring certain parameters, it may contain an educational component that encourages the patient to adopt changes in behavior and lifestyle ${ }^{7}$.

The teleconsult involves the real-time communication between the doctor and the patient by video conference or by telephone ${ }^{8}$. This method can be applied in almost all medical specialties, even those that require effective physical examination, as long as the patient is accompanied by another health professional able to perform the examination and report the results back to the doctor. Additional information can be transmitted during consultation, such as heart auscultation using a digital stethoscope or ultrasound-generated images during ultrasound, pulse oximetry, ECG monitoring ${ }^{9,10}$.

Teleconsultation, another aspect of telemedicine, refers to the communication between two or more health professionals about a certain medical problem or a complicated medical case, in order to obtain a second expert medical opinion and to develop a correct diagnosis and therapeutic plan ${ }^{11}$.

Through telehealth, with the help of advances in robotics and communication technology, safe and precise surgical interventions are performed, making possible the collaboration between surgeons from different medical centers in real time ${ }^{11}$.

Tele-education refers to the provision of general medical information, accessible to the general population, and also with the purpose of training medical personnel who can take online courses in order to ensure a continuous medical education ${ }^{12}$.

\section{TELEMEDICINE IN EUROPE}

Internet use among Europeans is constantly increasing, over $85 \%$ of EU households had access to the Internet in 2016, and more and more citizens are going online in order to obtain health information, medical services or to make appointments. More than half of European citizens searched online for health information in 2017, twice as many as in $2008^{13,14}$.

The electronic medical record, which contains a detailed history of the patient and which can be accessed by specialists in the medical field in hospitals or medical offices, was used in 2016 in over 15 Member States of the EU. In most of these countries, patients have access to data from their personal medical records, and in countries such as Denmark, Estonia, France, Greece, Latvia, Luxembourg, Spain and Sweden, patients can add or modify certain information ${ }^{15}$.

The European Commission has adopted a recommendation about the format for the exchange of electronic medical records between the Member States of the European Union, allowing access to patient data outside country borders. The first such exchange took place between Estonia and Finland in January 2019. By 2021, 22 Member States are expected to exchange electronic medical records ${ }^{16}$.

The prescription of electronic medical prescriptions without the need for a hard copy is successfully used in Finland, Estonia, Sweden, Denmark, Portugal and Spain, where in 2018 , over $90 \%$ of medical prescriptions have been prescribed electronically ${ }^{17}$. Prescriptions can be issued electronically for patients with chronic illnesses or following a teleconsultation without having to travel to the doctor's office.

Teleradiology is the most widespread tele-health program in the European Region, 38 Member States use it according to a study by WHO in 2016.

Remote patient monitoring is the second most widespread tele-health program, being used by 33 of the Member States ${ }^{18,19}$. There are telemonitoring services for diabetic patients, those with cardiovascular disease or COPD in countries such as Finland, Norway, Denmark, Germany, etc ${ }^{7}$.

Teledermatology is used in Estonia and Sweden, where general practitioners can contact a specialist dermatologist, when they discover a suspicious skin lesion, in order to detect early skin cancer. In Switzerland, patients can send photos of the lesions in specialized centers on dermatology ${ }^{7}$.

The teleneurology networks help the diagnosis process of ischemic strokes by means of teleconsult and 
Telemedicine in Europe - Current Status and Future Perspectives

evaluation of the CT scan by the neurology specialists, thereby allowing initiation of the rapid treatment by thrombolysis with significat improvement of the patient's prognosis ${ }^{20,21}$. Such programs exist in Germany, Scotland, Spain, Italy, etc., but they need to be extended to cover rural areas in European states ${ }^{21-23}$.

With the help of EU funding projects, the infrastructure of digital health services and trans-European networks have been developed. The first European Reference Networks (ERNs) were launched in March 2017, including over 900 highly specialized medical units in over 300 hospitals in 26 EU Member States. There are 24 ERNs designed to help patients with rare or complex diseases, they address a specific area of intervention, such as bone disease, cancer in children, autoimmune diseases, immunodeficiency, disorders and complications related to transplantation in children ${ }^{24,25}$. European reference networks are based on cross-border teleconsultation between several specialists in order to develop the optimal treatment plan for patients with rare or complex diseases ${ }^{26,27}$.

The number of downloads of health-related applications for smart devices (mobile Health or mHealth) increased dramatically between 2013 and 2017, from 1.7 billion to 3.7 billion, and the trend is still rising. A study showed that most mHealth applications were downloaded in the UK and Germany during this period, followed by Scandinavian countries. In Sweden,

\section{References}

1. World Health Organization. Telemedicine: opportunities and developments in Member States: report on the second global survey on eHealth 2010. Geneva: WHO; 2010

2. Kamsu-Foguem B, Foguem C. Could telemedicine enhance traditional medical practices? European Research in Telemedicine / La Recherche Européenne en Télémédecine, Elsevier Masson SAS, 2014;3(3):117-123.

3. Ciuhu AN, Rahnea Niță RA, Popescu M, et al. Evidence of strong opioid therapy for palliation of breathlesness in cancer patients. Farmacia 2017;65(2):173-178.

4. Eurostat. Internet use by individuals. Eurostat Press Office. 260/2016-20 December 2016 Available at http://ec.europa.eu/ eurostat/documents/2995521/7771139/9-20122016-BP-EN. pdf

5. Deldar K, Bahaadinbeigy K, Tara SM. Teleconsultation and clinical decision making: a systematic review. Acta Inform Med. 2016;24(4):286-292.

6. Raposo VL. Telemedicine: The legal framework (or the lack of it) in Europe. GMS Health Technol Assess. 2016;12:Doc03.

7. Diaconu C, Bălăceanu A, Bartoş D. Venous thromboembolism in pregnant woman - a challenge for the clinician. Central European Journal of Medicine 2013;8(5):548-552.

8. Mahar JH, Rosencrance JG, Rasmussen PA. Telemedicine: Past, present, and future. Cleveland Clinic Journal of Medicine. 2018; 85(12):938-942
$23 \%$ of the population used mHealth applications on smart devices in 2017, in Denmark 16\% and in Finland $15 \%{ }^{3}$. It is estimated that the global market for mHealth applications will reach over 38 billion euros by $2020^{28}$.

\section{CONCLUSIONS}

Telemedicine could be one of the solutions that can help address the challenges that EU Member States are facing, including the aging population, and an increasing number of chronic patients. In the future, more and more people will need medical care or support. The permanent development of new technologies that help patients and the decrease of the workforce in the health field are additional arguments for the implementation and use of telemedicine. It is important to note that telemedicine should be considered complementary to conventional medicine, rather than a substitute and that in some cases it cannot replace face to face interaction.

Compliance with ethics requirements: The authors declare no conflict of interest regarding this article. The authors declare that all the procedures and experiments of this study respect the ethical standards in the Helsinki Declaration of 1975, as revised in 2008(5), as well as the national law. Informed consent was obtained from all the patients included in the study.

9. Diaconu C, Bălăceanu A, Moroşan E. Sepsis biomarkers: past, present and future. Farmacia 2015;63(6):811-815.

10. Drăghici $T$, Negreanu $L$, Bratu $O G$, et al. Liver abnormalities in patients with heart failure. Arch Balk Med Union 2018;53(1):7681

11. Choi PJ, Oskouian RJ, Tubbs RS. Telesurgery: past, present, and future. Cureus 2018;10(5):e2716.

12. Masic I, Pandza H, Kulasin I, et al. Tele-education as method of medical education. Med Arh. 2009;63(6):350-3.

13. OECD/EU (2018), Health at a Glance: Europe 2018: State of Health in the EU Cycle, OECD Publishing, Paris. https://doi. org/10.1787/health_glance_eur-2018-en

14. Eurostat (2016), Methodological manual for statistics on the Information Society, https://circabc.europa.eu/faces/jsp/extension/wai/navigation/container.jsp

15. Diaconu C, Bălăceanu A, Bartoş D. Diuretics, first-line antihypertensive agents: are they always safe in the elderly? Romanian Journal of Internal Medicine 2014;52(2):87-90.

16. European Commission. Exchange of Electronic Health Records across the EU. https://ec.europa.eu/digital-single-market/en/ exchange-electronic-health-records-across-eu

17. OECD (2017), New Health Technologies: Managing Access, Value and Sustainability, OECD Publishing, Paris, https://doi. org/10.1787/9789264266438-en. 
Ana-Maria CIOTI et al.

18. WHO Regional office for Europe. From innovation to implementation. eHealth in the WHO European Region.2016 Available at http://www.euro.who.int/en/ehealth

19. Stănescu $A M A$, Grăjdeanu IV, Bratu $O G$, et al. Problematica comunicării medic-pacient în practica medicală. Modalități de abordare a pacientului în cazurile complicate. Revista Medicală Română 2018;LXV(2):98-101.

20. Bratu OG, Marcu RD, Socea B, et al. Immunohistochemistry particularities of retroperitoneal tumors. Rev Chim (Bucharest) 2018:69(7):1813-1816.

21. Stănescu AMA, Grajdeanu IV, Bejan GC, et al. Predicția prevalenței HIV pană în anul 2022 în România și Uniunea Europeană. Revista Medicală Română 2018;LXV(4):261-265.

22. Hubert GJ, Santo G, Vanjooren G, et al. Recommendations on telestroke in Europe. European Stroke Journal 2019;4(2):101109.

23. Stănescu AMA, Grajdeanu IV, Serban B, Bratu OG, Diaconu CC. Importanța supradiagnosticării în medicina de familie. Cum mi- nimalizăm riscurile? Revista Medicală Română 2019; LXVI(1): 29-33.

24. Ginghină O, Negrei $C$, Hudită $A$, et al. In vitro impact of some natural compounds on HT-29 colorectal adenocarcinoma cells. Farmacia 2017;65(6):947-953.

25. Bodean O, Bratu OG, Bohîltea R, et al. The efficacy of synthetic oral progestin pills in patients with severe endometriosis. Rev Chim (Bucharest) 2018;69(6):1411-1415.

26. Marcu RD, Spînu AD, Socea B, et al. Castleman's disease - clinical, histological and therapeutic features. Rev Chim (Bucharest) 2018;69(4): 823-830

27. Stănescu AMA, Grăjdeanu IV, Bratu OG, et al. Problematica comunicării medic-pacient în practica medicală. Modalități de abordare a pacientului în cazurile complicate. Revista Medicală Română 2018;LXV(2):98-101.

28. https://www.statista.com/statistics/387867/value-ofworldwide-digital-health-market-forecast-by-segment. 